\title{
VARIABILITY OF PHYSICOCHEMICAL PROPERTIES OF WATER OF THE TRANSBOUNDARY POPRAD RIVER
}

\author{
Agnieszka Policht-Latawiec'1, Andrzej Bogdał', Włodzimierz Kanownik', \\ Tomasz Kowalik ${ }^{1}$, Krzysztof Ostrowski ${ }^{1}$
}

1 Department of Land Reclamation and Environmental Development, University of Agriculture in Krakow, Al. Mickiewicza 24-28, 30-059 Krakow, Poland, e-mail: a.policht@ur.krakow.pl; rmbogdal@cyf-kr.edu.pl; rmkanown@cyf-kr.edu.pl; rmkowali@cyf-kr.edu.pl; rmostrow@cyf-kr.edu.pl

Received: 2014.07.10

Accepted: 2014.10.17

Published: 2015.01.02

\begin{abstract}
The results of five-year (2008-2012) hydrochemical research of the Poprad river, the right bank tributary to the Dunajec, were analyzed in the paper. The Poprad, $167 \mathrm{~km}$ long and with the catchment area of $2077.3 \mathrm{~km}^{2}$, flows for over $100 \mathrm{~km}$ through the territory of Slovakia, along the length of $31.1 \mathrm{~km}$ is a transboundary river, whereas its $31.0 \mathrm{~km}$ long reach is situated in Poland. Concerning its abiotic character, it is an eastern upland river of type 15 . The research was conducted in three measurement-control points: 1) located in Leluchów on the Polish-Slovak border at 61.1 kilometer of the river course, 2) in Piwniczna-Zdrój - $23.9 \mathrm{~km}$ and 3) in Stary Sącz - $2.9 \mathrm{~km}$ before the Poprad outlet to the Dunajec. 21 physicochemical indices and 2 microbiological indicators were assessed in the water samples once a month using referential methods. The paper assesses changes of water quality classes and its usable values along the analyzed Poprad river reach. Moreover, statistical differences between the values of individual indices assessed in various measurement-control points were estimated by means of Mann-Whitney U nonparametric test. On the basis of the conducted analyses of the empirical data it was stated that due to the physicochemical indices, water quality along the whole length of the analyzed river reach was good (class II) - in points 1 and 3 it was determined by mean concentration of total suspended solids, whereas in point 2 COD-Mn values.
\end{abstract}

Keywords: the Poprad river, physicochemical indices, ecological state, water pollution.

\section{INTRODUCTION}

Surface waters may be polluted by substances originating from anthropogenic sources [Grochowska and Tandyrak 2007, Bojakowska et al. 2010, Húska et al. 2013] and due to natural processes occurring in the environment [Moniewski and Stolarska 2007]. Natural sources may comprise various pollutant agents, such as plant remnants and humus substances, clay and silt particles of soils or rocks, compounds of iron and manganese, etc. However, pollution caused by various human activities is far more dangerous to the environment [Dąbrowska 2008, PolichtLatawiec and Kanownik 2013]. These may be either liquid or gaseous substances. They find their way directly to the waters, most frequently with various types of sewage, either municipal [Gromaire-Mertz et al. 1999, Göbel et al. 2007, Napieralska and Gołdyn 2013], industrial [Lewandowska-Robak 2011] or rural [Monaghan 2007]. Such pollutants are also in post-cooling waters, salinated mining wastewaters, surface runoffs from industrial and agricultural areas [Bogdał and Ostrowski 2007, Wiatkowski et al. 2012], leachates from industrial and municipal landfills [Kukuła and Bylak 2010]. Dangerous substances may find their way to surface waters also directly from the atmospheric air, to which dusts and gases are emitted by various industries [Vicario 2012]. The pollutants finding their way directly to waters are divided into three kinds, ac- 
cording to the way of their inflow: point source, line source and area source pollution [Paredes et al. 2010, Kleiber 2012]. Point source pollution reaches waters in a concentrated form in a specific place (e.g. municipal or industrial sewage discharge). Line source pollution is connected with the effect of pollutants along some course (e.g. streets with very heavy traffic) [Bąk et al. 2012, Wiśniowska-Kielian et al. 2013]. The area source pollution originates from rainwater runoff from urban areas without sewer system, from agricultural areas [Kanownik et al. 2011] or forest areas [Bogdał and Ostrowski 2009, Kowalik et al. 2012]. Disadvantageous changes of physical, chemical and biological properties of surface waters caused by anthropogenic factors lead to environmental changes, which unfavorably influence living organisms. Such a situation makes necessary undertaking a number of endeavors to prevent further degradation, which are preceded by research monitoring of rivers and water reservoirs threatened with anthropopressure, which allows to identify the hazards to surface waters in the catchments [Lampart-Kłużniacka et al. 2012, Brankov et al. 2012].

The aim of the paper was determining the changes of water quality along about $60 \mathrm{~km}$ long reach of the transboundary Poprad river. The authors strived to reach the objective through comparing the values of several dozen physicochemical indices and two microbiological indicators determined in 3 measurement-control points, which proved a basis for the assessment of water classes and usable values of the surface water.

\section{MATERIAL AND METHODS}

The object of analysis were values and concentrations of physicochemical and microbiological indices of the Poprad river water quality, investigated in 2008-2012 by the Regional Inspectorate of the Environmental Protection in Krakow. Water was sampled in three measurement-control points: the first located in Leluchów (on the Polish-Slovakian border) at km 61.2 of the river course, the second in Piwniczna-Zdrój $(23.9 \mathrm{~km})$ and the third in Stary Sacz at $2.9 \mathrm{~km}$ of the Poprad river course (Figure 1).

The Poprad is a transboundary river flowing from Slovakia to Poland. Concerning the abiotic factors, it is classified s eastern upland rivers, type 15. It has its source in the High Tatra Mts. in Slo- vakia, whereas the confluence of the Hińczowy Stream with the Krupa Stream is regarded as its headwaters. The Poprad river has numerous tributaries, among which the larger ones are the following streams: the Lipnik, the Suliński, the Granastowski, the Smereczek, the Muszynka with the Kryniczanka, the Wierchomlanka, the Łomniczanka, the Czerecz, the Wielka Roztoka and the Przysietnicki stream, in Biegionice village, situated about $2.9 \mathrm{~km}$ below Stary Sącz, the Poprad flows into the Dunajec on the right bank side (Figure 1).

The Poprad river is $167 \mathrm{~km}$ long and for over $100 \mathrm{~km}$ flows through the territory of Slovakia, on the $31.1 \mathrm{~km}$ reach it is a transboundary river (from Leluchów and Legnava to Piwniczna-Zdrój) and along $31.0 \mathrm{~km}$ it is situated on the territory of Poland. The catchment area is $2077.3 \mathrm{~km}^{2}$, of which $77 \%$ is situated in the area of Presov county in the Slovak Republic, whereas only $482.8 \mathrm{~km}^{2}$ in the southern part of the Nowy Sącz county in the Malopolska Voivodeship (Poland). The Slovak part of the catchment is situated in the Central part of the Western Carpathians (514) and partly comprises geographical regions such as the Eastern Tatra Mts. (514.53), Liptovsko-Spiska Depression (514), the Pieniny Mts. (514.12) and Spisko-Gubałowskie Foothills (514.13). On the Polish side its catchment belongs to the Outer Western Carpathians (513) and comprises almost whole Beskid Sądecki Mts. (513.54) and a part of Sącz Basin (513.53).

The Poprad flows through some larger cities, towns and villages, including: Poprad, Kežmarok and Stara L'ubovla (Slovakia) and Leluchów, Muszyna, Żegiestów-Zdrój, Piwniczna-Zdrój, Rytro and Stary Sącz (Poland). Therefore, the river water is drawn for municipal water supply, but at the same time the Poprad is a direct or indirect receiver of treated sewage, which is discharged from 8 sewage treatment plants: in Rytro (km 12+320), Piwniczna (km 21+580, the Borownice stream), Andrzejówka (the Andrzejówka stream), Żegiestów (km 35+500 and $40+400)$, Muszyna (km 51+350) and in Krynica (the Kryniczanka stream).

21 physicochemical indices and two microbiological indicators were determined in the water samples using referential methods [Rozporządzenie MŚ 2011b]. For each analyzed index minimum, maximum value, arithmetic mean, median, standard deviation and coefficient of variance were determined for the period of in- 


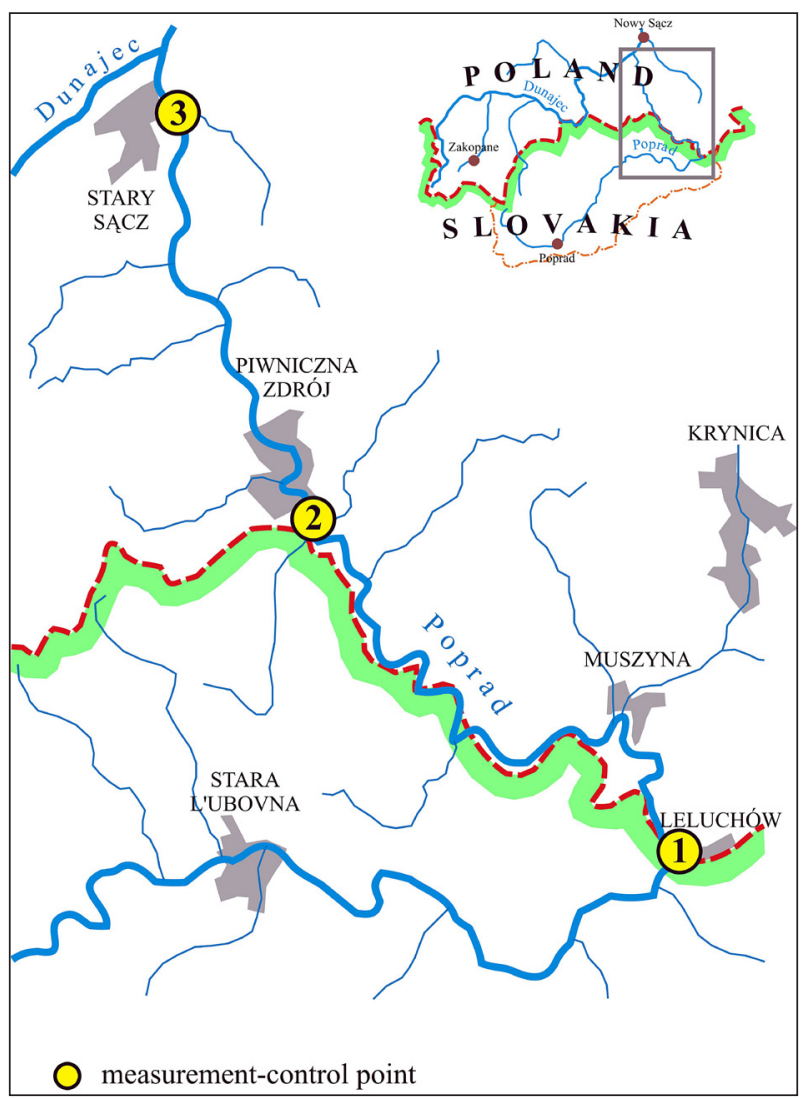

Figure 1. Location of water measurement-control points on the Poprad river

vestigations. Moreover, the empirical data sets were subjected to a comprehensive statistical analysis. It relied on previous testing the normality of distributions using Shapiro-Wilk test and regarding different numbers of samples, and estimation using non-parametric Mann-Whitney U test (on the significance level $\alpha=0.05$ ) of the significance of differences between the values of respective indices assessed in 1., 2. and 3. measurement-control points. A median, extreme values and 10-90 percentile were presented in box and whiskers diagrams for selected physicochemical water indices whose values differed significantly between the points.

The assessment of the Poprad water quality in each measurement-control point was conducted in compliance with the Resolution of the Minister of the Natural Environment of 9 November 2011 on the classification of uniform parts of surface waters [Rozporządzenie MŚ 2011a]. Usable values of water were assessed on the basis of the Resulution of the Minister of the Natural Environment of 27 November 2002 on the requirements for surface water used for drinking water supply [Rozporządzenie MŚ 2002b] and in compliance with the Decree of the Minister of the Natural Environment of 4 October 2002 on the requirements for fresh waters which are the fish habitat under natural conditions [Rozporządzenie MŚ 2002a].

\section{RESULTS}

The temperature of the Poprad river in points 2. and 3. On all dates of measurements did not exceed the value permissible for class I $\left(22^{\circ} \mathrm{C}\right)$, in point 1 . The maximum value was $23.5^{\circ} \mathrm{C}$. Mean value in two first points was almost identical, on the level of respectively 9.3 and $9.4^{\circ} \mathrm{C}$, whereas in the by-the-mouth point the water temperature was on average about $1{ }^{\circ} \mathrm{C}$ higher. Therefore, water was classified to the first quality class (Table 1). Mean concentrations of total suspended solids in the subsequent measurement-control points were on the level of: $31.9,24.0$ and $29.5 \mathrm{mg} \cdot \mathrm{dm}^{-3}$, therefore the permissible value for class I waters, i.e. $25 \mathrm{mg} \cdot \mathrm{dm}^{-3}$ was not exceeded only in point 2 . [Rozporządzenie MŚ 2011a]. In other two points average values of this physical index allowed to classify water to class II (Table 1). At the respective dates of measurements the changes of quality caused by total suspended solids were dynamic, because in quite numerous water samples (1 $14.4 \%, 2-15.0 \%$ and $3-18.35 \%$ ) they did not 
Table 1. Selected descriptive statistics for physicochemical indices and microbiological indicators, and quality water class

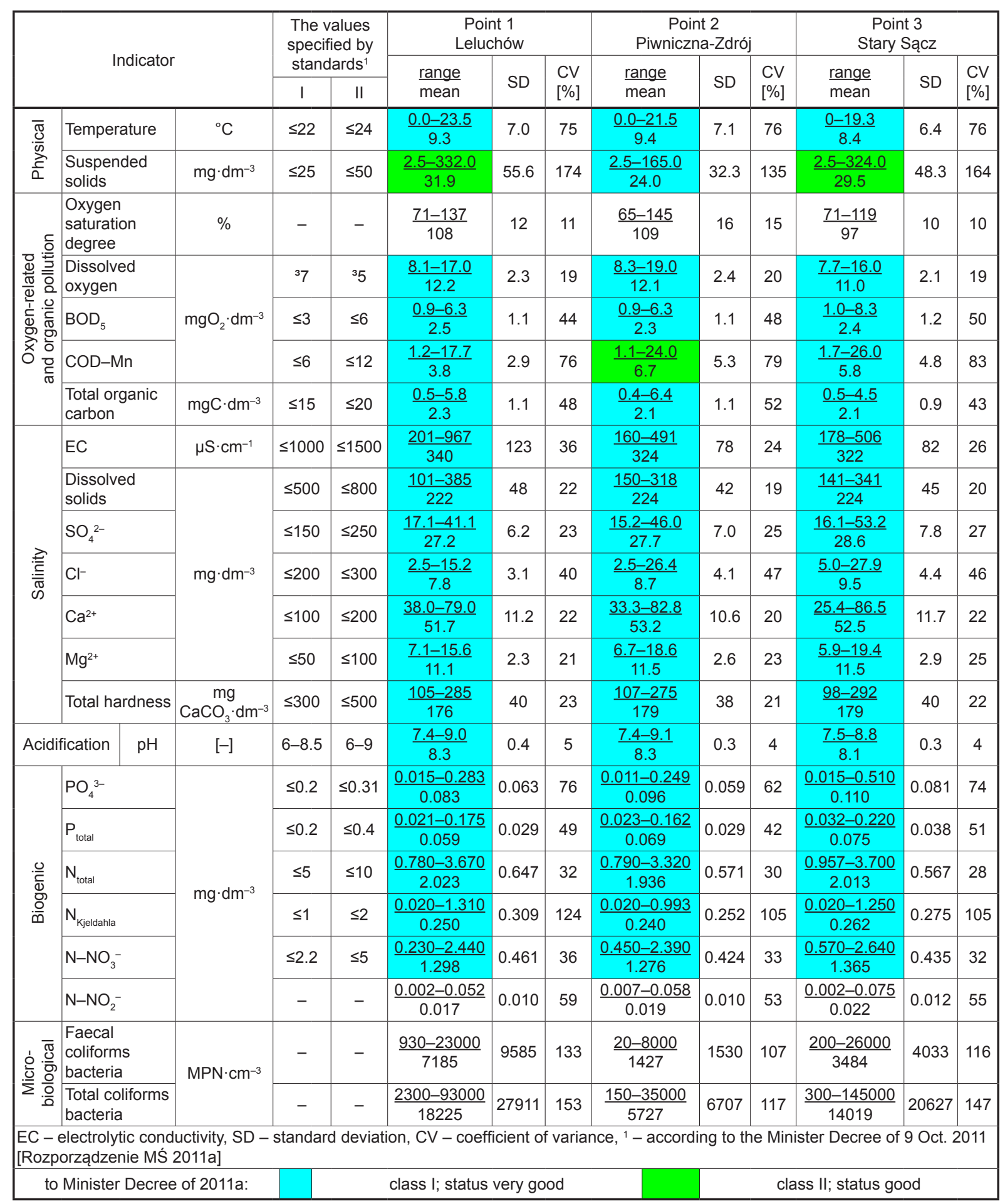

was most frequent in point 1. (Figure 2). An average value and median of chemical oxygen demand (COD-Mn) was clearly the highest in the central measurement-control point, particularly in comparison with point 1 (Table 1, Figure 3), as evidenced statistically on $\alpha=0.05$ level (Table 2 ). For these reasons, physicochemical status of water on the border of the two countries (1) and in by-the mouth point (3) was very good, whereas in Piwniczna-Zdrój it was good (Table 1).

The values of seven investigated salinity indices (electrolytic conductivity, dissolved solids, sulfates, chlorides, calcium, magnesium and total hardness) were similar in all analyzed points and remained on a low level with reference to the values permissible for class I waters. They did not 
Table 2. The significance of differences between the values of water measurement-control points - the median values and the probability of the Mann-Whitney U test

\begin{tabular}{|c|c|c|c|c|c|c|c|c|c|c|}
\hline \multirow{3}{*}{ Indicator } & \multirow{3}{*}{ Unit } & \multicolumn{3}{|c|}{$\begin{array}{c}\text { Medians in } \\
\text { measurement-control point }\end{array}$} & \multicolumn{6}{|c|}{$\begin{array}{l}\text { The test value }(Z) \text { and the probability of the test }(p) \\
\text { in the variants calculation }\end{array}$} \\
\hline & & \multirow{2}{*}{ Point 1} & \multirow{2}{*}{ Point 2} & \multirow{2}{*}{ Point 3} & \multicolumn{2}{|c|}{ Point 1-2 } & \multicolumn{2}{|c|}{ Point 2-3 } & \multicolumn{2}{|c|}{ Point 1-3 } \\
\hline & & & & & $Z$ & $p$ & $z$ & $p$ & Z & $p$ \\
\hline Temperature & ${ }^{\circ} \mathrm{C}$ & 9.1 & 9.7 & 8.7 & -0.03 & 0.98 & 0.82 & 0.41 & 0.78 & 0.43 \\
\hline Suspended solids & $\mathrm{mg} \cdot \mathrm{dm}^{-3}$ & 11.3 & 9.6 & 12.0 & 0.28 & 0.78 & -0.85 & 0.39 & -0.43 & 0.67 \\
\hline $\begin{array}{l}\text { Oxygen saturation } \\
\text { degree }\end{array}$ & $\%$ & 107 & 107 & 96 & -0.11 & 0.91 & 4.84 & 0.00 & 4.87 & 0.00 \\
\hline Dissolved oxygen & \multirow{3}{*}{$\mathrm{mgO}_{2} \cdot \mathrm{dm}^{-3}$} & 12.3 & 12.0 & 10.7 & 0.18 & 0.86 & 2.50 & 0.01 & 2.51 & 0.01 \\
\hline $\mathrm{BOD}_{5}$ & & 2.3 & 2.0 & 2.2 & 1.06 & 0.29 & -0.10 & 0.92 & 0.92 & 0.36 \\
\hline COD-Mn & & 3.1 & 5.0 & 4.2 & -3.44 & 0.00 & 1.11 & 0.27 & -2.38 & 0.02 \\
\hline Total organic carbon & $\mathrm{mgC} \cdot \mathrm{dm}^{-3}$ & 2.4 & 2.2 & 2.2 & 1.46 & 0.15 & -0.15 & 0.88 & 1.27 & 0.20 \\
\hline$E C$ & $\mu S \cdot \mathrm{cm}^{-1}$ & 319 & 315 & 308 & -0.04 & 0.97 & 0.39 & 0.70 & 0.34 & 0.74 \\
\hline Dissolved solids & \multirow{5}{*}{$\mathrm{mg} \cdot \mathrm{dm}^{-3}$} & 221 & 224 & 220 & -0.26 & 0.80 & 0.14 & 0.89 & -0.12 & 0.90 \\
\hline $\mathrm{SO}_{4}^{2-}$ & & 27.5 & 27.5 & 29.0 & -0.31 & 0.76 & 0.46 & 0.64 & -0.70 & 0.48 \\
\hline $\mathrm{Cl}^{-}$ & & 7.9 & 8.2 & 8.6 & -0.75 & 0.45 & -1.19 & 0.23 & -1.61 & 0.11 \\
\hline $\mathrm{Ca}^{2+}$ & & 27.9 & 53.3 & 51.9 & -1.04 & 0.30 & 0.32 & 0.74 & -0.83 & 0.41 \\
\hline $\mathrm{Mg}^{2+}$ & & 11.4 & 11.9 & 11.7 & -0.78 & 0.44 & 0.11 & 0.91 & -0.68 & 0.50 \\
\hline Total hardness & $\mathrm{mgCaCO}_{3} \cdot \mathrm{dm}^{-3}$ & 167 & 181 & 178 & -0.59 & 0.55 & 0.15 & 0.88 & -0.61 & 0.54 \\
\hline $\mathrm{pH}$ & {$[-]$} & 8.4 & 8.3 & 8.2 & 0.79 & 0.43 & 3.31 & 0.00 & 3.38 & 0.00 \\
\hline $\mathrm{PO}_{4}^{3-}$ & \multirow{6}{*}{$\mathrm{mg} \cdot \mathrm{dm}^{-3}$} & 0.072 & 0.086 & 0.087 & -1.40 & 0.16 & -0.83 & 0.41 & -2.17 & 0.03 \\
\hline$P_{\text {total }}$ & & 0.056 & 0.063 & 0.063 & -2.05 & 0.04 & -0.56 & 0.58 & -2.44 & 0.02 \\
\hline$N_{\text {total }}$ & & 1.937 & 1.804 & 1.900 & 0.86 & 0.39 & -0.84 & 0.40 & 0.27 & 0.79 \\
\hline$N_{\text {Kjeldahl }}$ & & 0.134 & 0.155 & 0.165 & -0.67 & 0.51 & -0.70 & 0.49 & -1.26 & 0.21 \\
\hline $\mathrm{N}-\mathrm{NO}_{3}^{-}$ & & 1.200 & 1.200 & 1.300 & 0.45 & 0.65 & -1.24 & 0.22 & -0.64 & 0.52 \\
\hline $\mathrm{N}-\mathrm{NO}_{2}^{-}$ & & 0.015 & 0.017 & 0.018 & -1.29 & 0.20 & -1.20 & 0.23 & -2.20 & 0.03 \\
\hline Fecal coliform bacteria & \multirow{2}{*}{$\mathrm{MPN} \cdot \mathrm{cm}^{-3}$} & 2300 & 930 & 2300 & 2.85 & 0.00 & -4.12 & 0.00 & 0.78 & 0.44 \\
\hline Total coliform bacteria & & 4300 & 2750 & 9050 & 2.03 & 0.04 & -3.92 & 0.00 & -0.47 & 0.64 \\
\hline Bold type indicates sign & I UIIEIEIIC & $=0.05)$ & & & & & & & & \\
\hline
\end{tabular}

meet the requirements for class II - below the good state. A great dynamics of changes was evidenced also by high values of the coefficient of variance $(135-174 \%)$. Like in case of the temperature, medians of total suspended solids did not differ statistically between the measurementcontrol points (Table 2).

Concentrations of oxygen dissolved in water along the studied Poprad river reach ranged from 7.7-19.0 $\mathrm{mgO}_{2} \cdot \mathrm{dm}^{-3}$. Means in points 1 and 2 differed slightly and were respectively 12.2 and 12.1 $\mathrm{mgO}_{2} \cdot \mathrm{dm}^{-3}$, whereas in point 3 the amount of oxygen in water was much smaller $-11.0 \mathrm{mgO}_{2} \cdot \mathrm{dm}^{-3}$. All research values and mean concentrations were higher than $7 \mathrm{mgO}_{2} \cdot \mathrm{dm}^{-3}$, i.e. they met the requirements for class I. Also water saturation with oxygen was high in all measurement-control points because the average values in the subsequent points were on the level of 108, 109 and
97\% (Table 1). Values of dissolved oxygen and water saturation with oxygen did not differ statistically between points 1 . and 2., but between 2. and 3., and between 1. and 3. values of MannWhitney $\mathrm{U}$ test confirmed significant differences (Table 2, Figure 3). A significant decrease in oxygen content in water between Piwniczna-Zdrój and Stary Sącz is mainly affected by a lower longitudinal rive profile along this reach, thus a less turbulent water flow, which does not favor intensive oxygen diffusion from the atmospheric air.

Mean $\mathrm{BOD}_{5}$ and total organic carbon (TOC) values were on a very similar level in all analyzed profiles and allowed to classify water to class I (Table 1). In case of the first index mentioned above, the values exceeding permissible levels for classes I and II were registered in single water samples with various frequency over the whole period of investigations. A worse water quality 

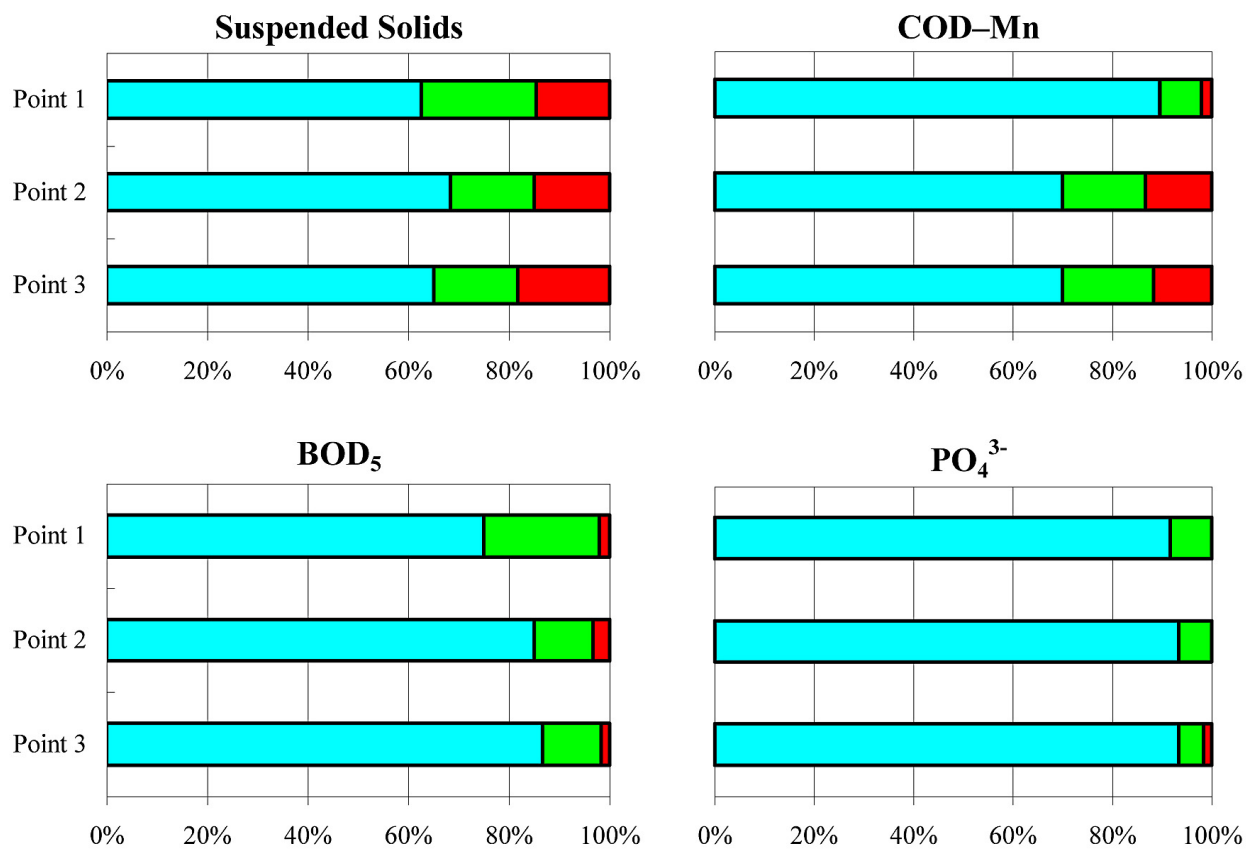

Quality class: $\mathrm{I}$ II $\mathrm{BGS}$ BGS - below good status

Figure 2. Proportion (\%) of values of individual water indices in water quality classes

differ statistically significantly either between the points (Table 1 and 2). Water flowing in the Poprad river may be considered as soft or medium hard because its total hardness in various months of the investigations fluctuated mostly from 100 to $300 \mathrm{CaCO}_{3} \cdot \mathrm{dm}^{-3}$ (Table 1)

On the basis of $\mathrm{pH}$ value intervals from 7.4-9.0, 7.4-9.1 and 7.5-8.8, respectively in the first, second and third measurement-control points, water $\mathrm{pH}$ may be stated between neutral and alkaline. Despite significant differences of $\mathrm{pH}$ values between points 2 and 3 and 1 and 3 , water reaction in all points and at all dates of research met the requirements for class I (Table 1 and 2, Figure 3). In Stary Sącz (point 3) mean concentrations of the analyzed biogenic indices, except total nitrogen, were higher than in the two other points (Table 1). Significant differences between points 1 and 3. occurred for nitrite nitrogen, phosphates and total phosphorus, and between points 1 . and 2 for total phosphorus (Table 2, Figure 3). On account of biogenic substances, the state of the Poprad river along the investigated reach was very good, because mean values of total, Kjeldahl and nitrate nitrogen, as well as phosphates and total phosphorus met the requirements of class I. Only in very few water samples (6.7-8.3\% at all sampling dates) phosphate concentrations exceeding values permis- sible for class I $\left(0.2 \mathrm{mg} \cdot \mathrm{dm}^{-3}\right)$ were registered (Figure 2).

The analysis of microbiological indicators revealed the lowest amounts of coliform bacteria and fecal coliform bacteria in water in point 2. (Table 1 and 2). Therefore, it may be said that along the reach from the Polish-Slovak border to Piwniczna-Zdrój water parameters improved, whereas along the river reach to Stary Sacz the Poprad water became again polluted with these bacteria (Figure 3).

Water in all studied measurement-control points did not meet the requirements for surface water used for drinking water supply because of too frequent turbidity caused by high concentrations of total suspended solids exceeding $35 \mathrm{mg} \cdot \mathrm{dm}^{-3}$ (Table 3 ). On the other hand, microbiological conditions in the Poprad river might make possible water use for consumption after a high performance physical and chemical treatment, appropriate for waters of A3 category. Moreover, usable values in all investigated points slightly worsened the values of biochemical oxygen demand $\left(\mathrm{BOD}_{5}\right)$ and $\mathrm{pH}$ value in point 1 , which allowed for water classification to category A2 [Rozporządzenie 2002b]. Other indices met the requirements for the best quality surface waters, i.e. category A1 (Table 3).

Water of the investigated reach of the Poprad river is unsuitable as a habitat for Salmo- 
Dissolved oxygen $\left[\mathrm{mgO}_{2} \cdot \mathrm{dm}^{-3}\right]$

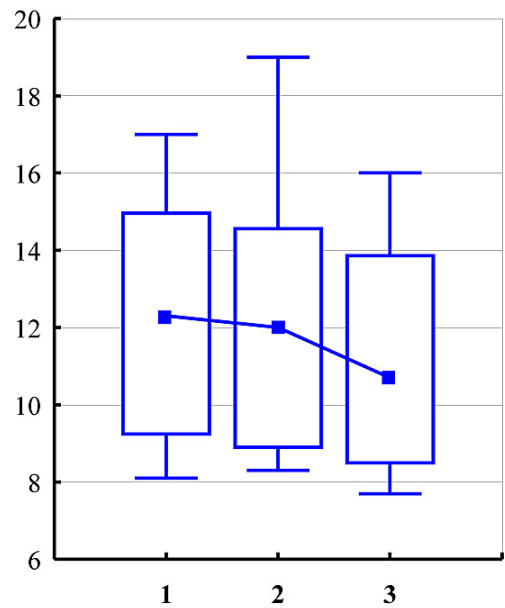

Number of measurement-control point

Nitrites $\left[\mathbf{m g} \cdot \mathbf{d m}^{-3}\right]$

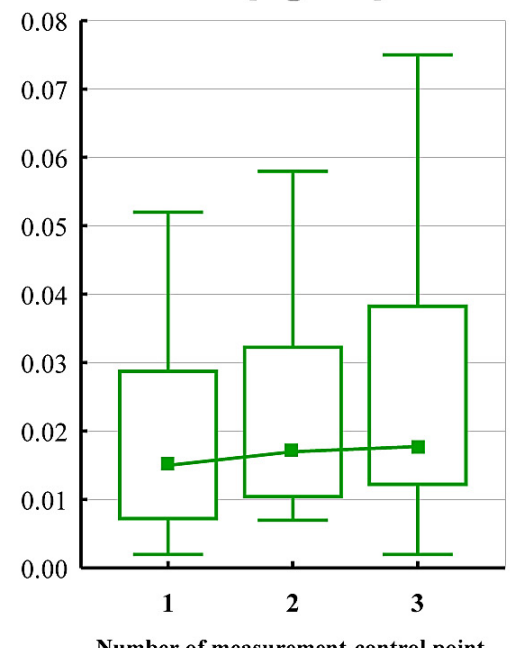

Number of measurement-control point

pH [-]

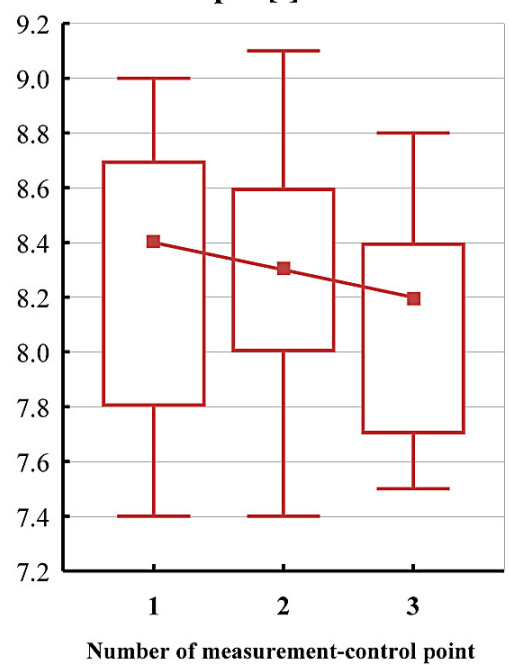

Oxygen saturation degree [\%]

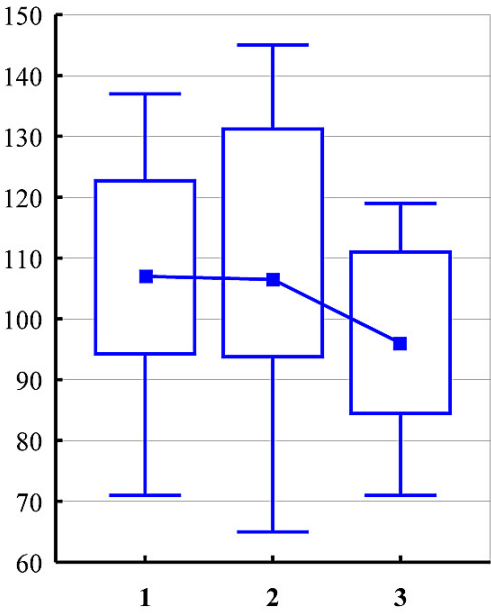

Number of measurement-control point

Phosphates $\left[\mathrm{mg} \cdot \mathbf{d m}^{-3}\right]$

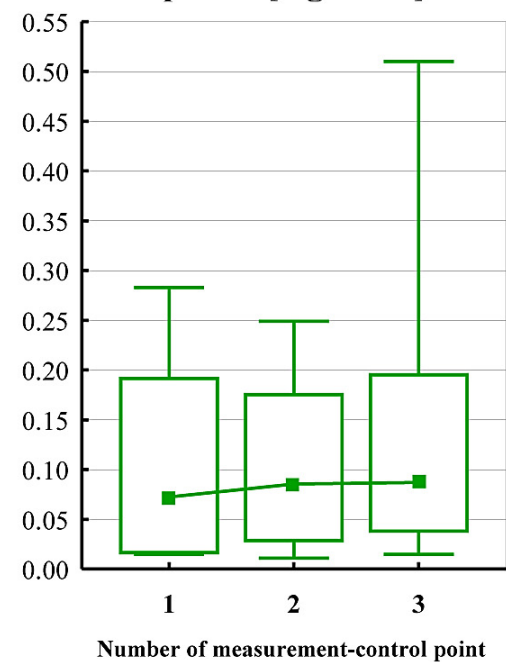

Faecal coliforms $\left[10^{3} \mathrm{MPN} \cdot \mathrm{cm}^{-3}\right]$

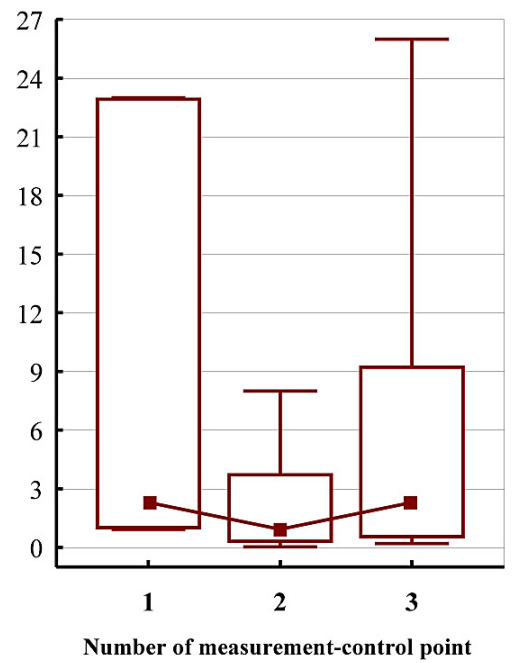

COD-Mn $\left[\mathrm{mgO}_{2} \cdot \mathrm{dm}^{-3}\right]$

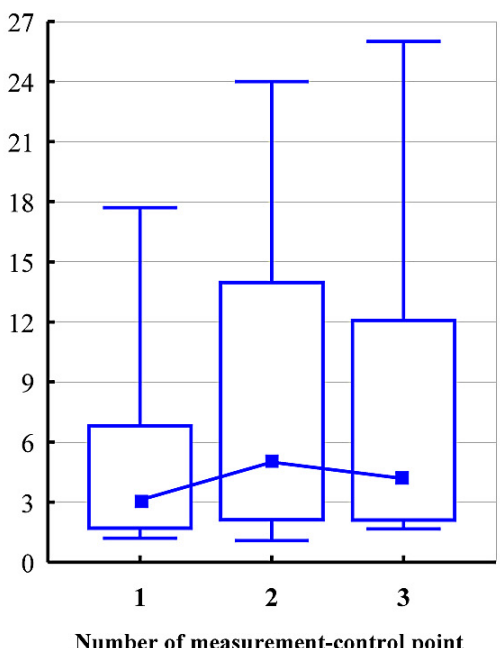

Total phosphorus $\left[\mathrm{mg} \cdot \mathrm{dm}^{-3}\right]$

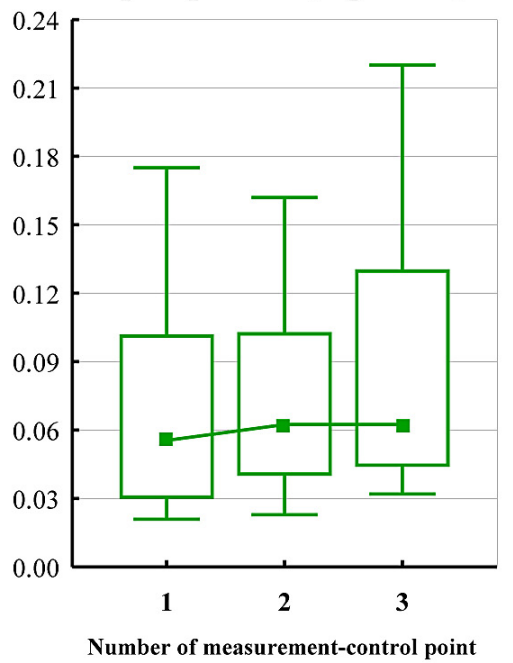

Number of measurement-control point

Total coliforms $\left[10^{3} \mathrm{MPN} \cdot \mathrm{cm}^{-3}\right]$ 160

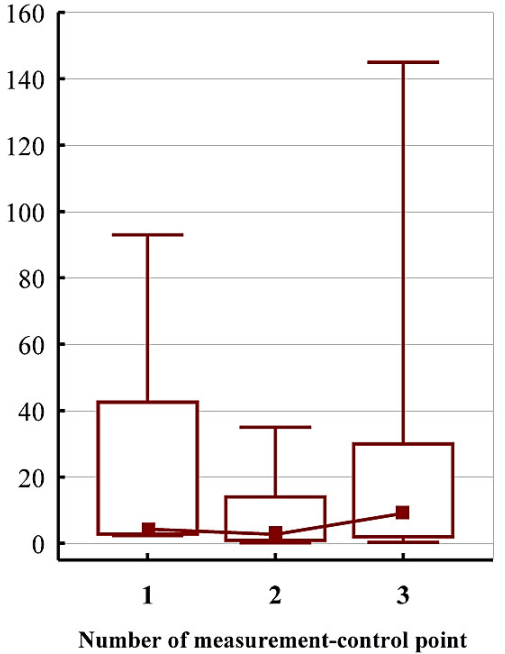

Median $\square$ Percentile 10-90\% 工 $工$ Min.-Max.

Figure 3. Variability of selected water quality indices along the analyzed Poprad river reach 
Table 3. Assessment of suitability for drinking water supply

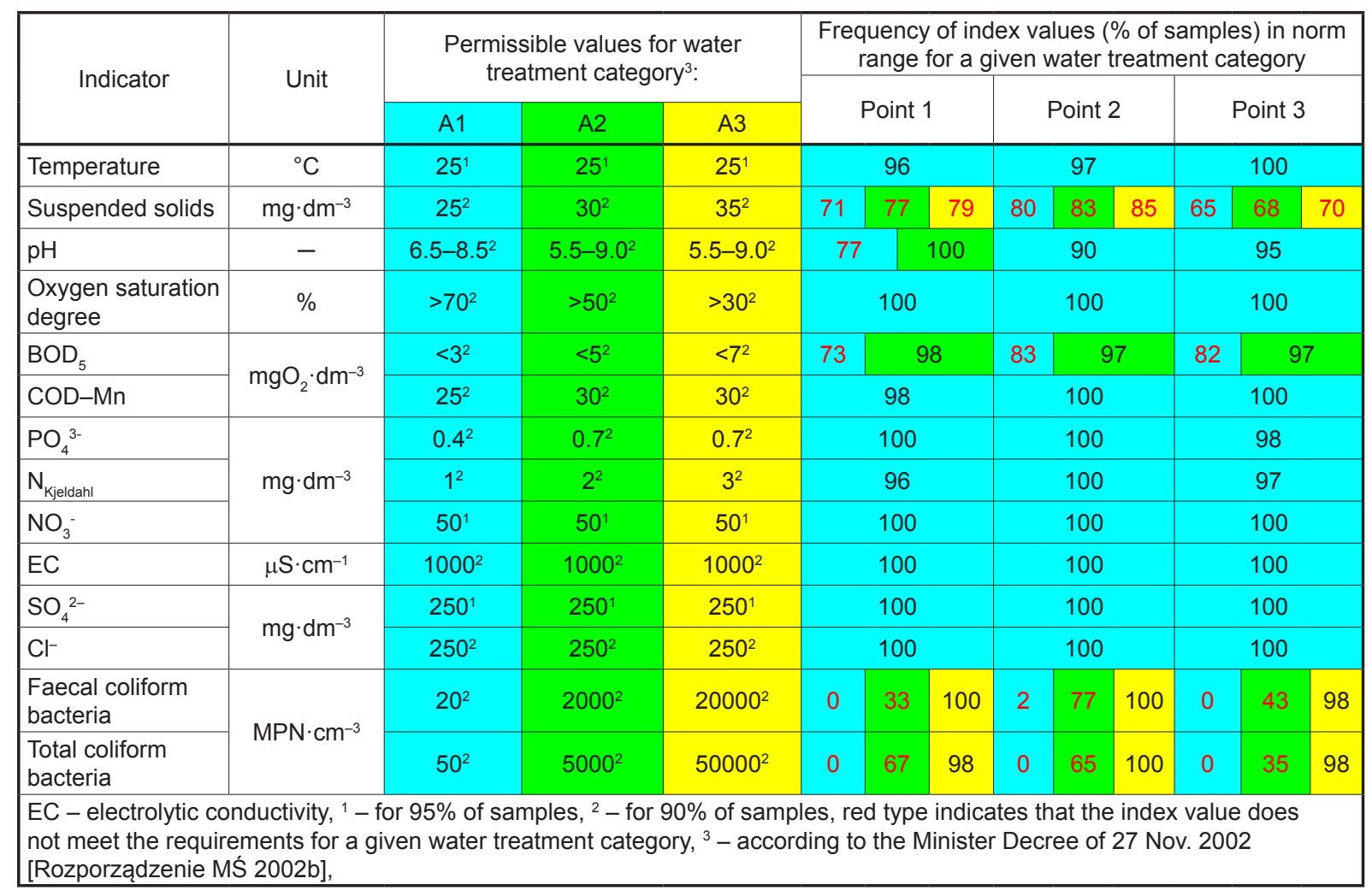

Table 4. Assessment of water usability as a natural habitat for fish

\begin{tabular}{|c|c|c|c|c|c|c|c|c|c|}
\hline \multirow{3}{*}{ Indicator } & \multirow{3}{*}{ Unit } & \multirow{2}{*}{\multicolumn{2}{|c|}{$\begin{array}{c}\text { Values required for } \\
\text { fresh waters as habitat } \\
\text { for fish }{ }^{4}:\end{array}$}} & \multicolumn{6}{|c|}{$\begin{array}{l}\text { Frequency of index values (\% of samples) in standard range } \\
\text { for a given fish category }\end{array}$} \\
\hline & & & & \multicolumn{3}{|c|}{ salmonids } & \multicolumn{3}{|c|}{ cyprinids } \\
\hline & & salmonids & cyprinids & point 1 & point 2 & point 3 & point 1 & point 2 & point 3 \\
\hline Temperature & ${ }^{\circ} \mathrm{C}$ & $21.5^{2}$ & $28.0^{2}$ & 98 & 100 & 100 & 100 & 100 & 100 \\
\hline Suspended solids & $\mathrm{mg} \cdot \mathrm{dm}^{-3}$ & \multicolumn{2}{|c|}{ mean annual value $\leq 25$} & $31.9^{3}$ & $24^{3}$ & $29.5^{3}$ & $31.9^{3}$ & $24^{3}$ & $29.5^{3}$ \\
\hline $\mathrm{pH}$ & - & \multicolumn{2}{|c|}{$6-9^{1}$} & 100 & 98 & 100 & 100 & 98 & 100 \\
\hline \multirow{2}{*}{ Dissolved oxygen } & \multirow{3}{*}{$\mathrm{mg} \mathrm{O}_{2} \cdot \mathrm{dm}^{-3}$} & $50 \% \geq 9$ & $50 \% \geq 8$ & $95 \% \geq 9$ & $90 \% \geq 9$ & $95 \% \geq 9$ & $100 \% \geq 8$ & $100 \% \geq 8$ & $93 \% \geq 8$ \\
\hline & & $100 \% \geq 7$ & $100 \% \geq 5$ & $100 \% \geq 7$ & $100 \% \geq 7$ & $100 \% \geq 7$ & $100 \% \geq 5$ & $100 \% \geq 5$ & $100 \% \geq 5$ \\
\hline $\mathrm{BOD}_{5}$ & & $\leq 3^{1}$ & $\leq 6^{1}$ & 80 & 85 & 87 & 98 & 97 & 98 \\
\hline$P_{\text {total }}$ & \multirow{2}{*}{$\mathrm{mg} \cdot \mathrm{dm}^{-3}$} & $\leq 0.2^{1}$ & $\leq 0.4^{1}$ & 100 & 100 & 97 & 100 & 100 & 100 \\
\hline $\mathrm{NO}_{2}^{-}$ & & $\leq 0.01^{1}$ & $\leq 0.03^{1}$ & 2 & 0 & 2 & 15 & 2 & 5 \\
\hline \multicolumn{10}{|c|}{$\begin{array}{l}1 \text { - for } 95 \% \text { of samples, }{ }^{2} \text { - for } 98 \% \text { of samples, }{ }^{3} \text { - average value, }{ }^{4} \text { - according to the Minister Decree of } 4 \text { Oct. } 2002 \\
{[\text { Rozporządzenie MŚ 2002a] }}\end{array}$} \\
\hline \multicolumn{10}{|c|}{ requirements fulfilled } \\
\hline
\end{tabular}

nid and Cyprinid fish under natural conditions in all studied points, due to high concentrations of nitrites and total suspended solids in points 1 . and 2. Also, due to $\mathrm{BOD}_{5}$ researched water does not create conditions suitable for Salmonid fish. Values of the temperature, $\mathrm{pH}$, dissolved oxygen and total phosphorus fulfilled the requirements stated for fresh waters which are the habitat of Salmonid and Cyprinid fish under natural conditions (Table 4).

\section{CONCLUSIONS}

1. From among 19 investigated quality indices, 17 meet the requirements for water quality class I - very good state in each measurementcontrol point. The Poprad river along the whole $60 \mathrm{~km}$ - long investigated reach reveals a good state due to total suspended solids concentrations in points 1. and 3., and chemical oxygen demand (COD-Mn) in point 2 . 
2. Due to too frequent occurrences of total suspended solids concentrations, waters of the Poprad river do not fulfill the requirements for surface waters used for drinking water supply to people. Because of a high number of coliform and fecal coliform bacteria, a high performance water treatment processes should be applied (category A3) in order to obtain water for consumption.

3. Along the studied river reach water did not meet the requirements for natural habitat of Salmonid fish of Salmo spp., Coregonidae (Coregonus) family or for Thymallus thymallus, fish from the Cyprinid family, or other species, such as Esox Lucius, Perca fluviatilis or Anguilla anguilla, mainly due to high concentrations of nitrites.

4. Statistical analysis revealed significantly elevated concentrations of nitrite nitrogen, total phosphorus, phosphates and COD-Mn, but the values of $\mathrm{pH}$, oxygen content and water saturation declined along the whole investigated river segment.

\section{REFERENCES}

1. Bąk Ł., Górski J., Górska K., Szeląg B. 2012. Zawartość zawiesin i metali ciężkich w wybranych falach ścieków deszczowych w zlewni miejskiej. Ochrona Środowiska, 2(34), 49-52.

2. Bogdał A. Ostrowski K. 2007. Wpływ rolniczego użytkowania zlewni podgórskiej i opadów atmosferycznych na jakość wód odpływających z jej obszaru. Woda-Środowisko-Obszary Wiejskie, Wyd. Falenty, 7, 2a (20), 59-69.

3. Bogdał A., Ostrowski K. 2009. Loads of selected components supplied with precipitation and flowing away from the area of two small catchments with diversified use. Acta Sci. Pol., Formatio Circumiectus, 8 (1-2) 2009, 35-45.

4. Bojakowska I., Gliwicz T., Kozłowska O., Szyborska-Kaszycka J. 2010. Charakterystyka geochemiczna wód rzeki Wieprz. Górnictwo i Geologia, 5 (4), 51-62.

5. Brankov J., Milijasević D., Milanović A. 2012. The Assessment of the Surface Water Quality Using the Water Pollution Index: A Case study of the Timok River (the Danube River Basin), Serbia. Archives of Environmental Protection, 38 (2), 49-61.

6. Dąbrowska J. 2008. Ocena zawartości związków azotu i fosforu w wodach rzeki Trzemny. Infrastruktura i Ekologia Terenów Wiejskich, 7, 57-68.
7. Göbel P., Dierkes C., Coldewey W.G. 2007. Storm water runoff concentration matrix for urban areas. J. Contaminant Hydrol., 91(1-2), 26-42.

8. Grochowska J., Tandyrak R. 2007. Nitrogen and Phosphorus Compounds in Lake Pluszne. Archives of Environmental Protection, 33 (1), 45-59.

9. Gromaire-Mertz M.C., Garnaud S., Gonzalez A., Chebbo G. 1999. Characterization of urban runoff pollution in Paris. Water Sci. Technol., 39(2), 1-8.

10. Húska D., Krupová K., Halaj P., Mandalová K. 2013. Ewaluation of surface water Žitava catchment under the aspect of anthropogenicimpact. Acta Sci. Pol. Formatio Circumiectus, 12(3), 41-51.

11. Kanownik W., Kowalik T., Bogdał A., Ostrowski K., Rajda W. 2011. Jakość i i walory użytkowe wody potoku Szczyrzawy. Zesz. Prob. Post. Nauk Rol., 561, 65-81.

12. Kleiber T. 2012. Pollution of the natural environment in intensive Cultures Under Greenhouses. Archives of Environmental Protection, 38 (2), 45-53.

13. Kowalik T., Bogdał A., Kanownik W., Borek Ł. 2012. Sezonowość zmian wartości wybranych właściwości fizykochemicznych wody odpływającej z małej zlewni rolniczo-leśnej. Gaz, Woda i Technika Sanitarna, 8, 354-357.

14. Kukuła K., Bylak A. 2011. Wpływ czynników antropogenicznych na faunę karpackich dopływów Wisły. Roczniki Bieszczadzkie, 19, 207-222.

15. Lampart-Kałużniacka M., Wojcieszonek A., Pikuła K. 2012. Ocena stanu ekologicznego wód rzeki Regi na odcinku w obszarze miasta Gryfice. Annual Set The Environment Protection / Rocznik Ochrony Środowiska, 14, 437- 446.

16. Lewandowska-Robak M., Górski Ł., Kowalkowski T., Dąbkowska-Naskręt H., Miesikowska I. 2011. Wpływ ścieków oczyszczonych odprowadzanych z Oczyszczalni Ścieków w Tucholi na jakość wody w strudze Kicz. Inżynieria i Ochrona Środowiska, 14 (3), 209-221.

17. Monaghan R.M., Wilcock R.J., Smith L.C., Tikkisetty B. Thorrold B.S., Costall D. 2007. Linkages between land management activities and water quality in an intensively farmed catchment in southern New Zealand. Agriculture, Ecosystems and Environment, 118, 211-222.

18. Moniewski P., Stolarska M. 2007. Wpływ naturalnych i antropogenicznych czynników na podstawowe charakterystyki fizykochemiczne wody w małej zlewni strefy podmiejskiej Łodzi. WodaŚrodowisko-Obszary Wiejskie, 7, 1(19), 105-122.

19. Napieralska A., Gołdyn R. 2013. Sanitary Analyses of Runoff Water a River. Pol. J. Environ. Stud., 22, 2, 481-486.

20. Paredes J., Andreu J., Solera A. 2010. A decision support system for water quality issues in the Man- 
zanares River (Madrid, Spain). Science of the Total Environment, 408, 2576-2589.

21. Policht-Latawiec A., Kanownik W. 2013. Jakość i walory użytkowe wody rzeki Szabasówki. Acta Sci. Pol., Formatio Circumiectus, 12(2), 93-102.

22. Rozporządzenie Ministra Środowiska z dnia 27 listopada 2002 r. w sprawie wymagań, jakim powinny odpowiadać wody powierzchniowe wykorzystywane do zaopatrzenia ludności w wodę przeznaczoną do spożycia. Dz. U. Nr 204, poz.1728. 2002b

23. Rozporządzenie Ministra Środowiska z dnia 4 października 2002 r. w sprawie wymagań, jakim powinny odpowiadać wody śródlądowe będące środowiskiem życia ryb w warunkach naturalnych. Dz. U. Nr 176, poz. 1455. 2002a

24. Rozporządzenie Ministra Środowiska z dnia 9 listopada 2011 r. w sprawie klasyfikacji stanu ekologicznego, potencjału ekologicznego i stanu chemic- znego jednolitych części wód powierzchniowych. Dz. U. Nr 258, poz. 1549. 2011a

25. Rozporządzeniem Ministra Środowiska z dnia 15 listopada 2011 r. w sprawie form i sposobu prowadzenia monitoringu jednolitych części wód powierzchniowych i podziemnych. Dz. U. Nr 258, poz. 1550. 2011b

26. Vicario L. 2012. Zanieczyszczenie powietrza i zagrożenie hałasem [dokument elektroniczny: www.europarl.europa.eu/ftu/pdf/pl/ FTU_4.10.6.pdf, dostęp: 15.10.2012 r.].

27. Wiatkowski M., Rosik-Dulewska Cz., Gruss Ł. 2012. Profil zmian wskaźników jakości wody w rzece Stobrawie. Infrastruktura i Ekologia Terenów Wiejskich, 3, 21-35.

28. Wiśniowska-Kielian B., Niemiec M., Arasimowicz M. 2013. Przydrożne zbiorniki ścieków opadowych jako element ochrony jakości wód. Inżynieria Ekologiczna, 34, 62-75. 